\title{
Gasification of Iranian walnut shell as a bio-renewable resource for hydrogen-rich gas production using supercritical water technology
}

\author{
Farid Safari $^{1} \cdot$ Ahmad Tavasoli $^{1,2} \cdot$ Abtin Ataei $^{1}$
}

Received: 25 November 2015/Accepted: 15 August 2016/Published online: 24 August 2016

(C) The Author(s) 2016. This article is published with open access at Springerlink.com

\begin{abstract}
Gasification in supercritical water (SCW) media is known as an efficient and promising technology for obtaining hydrogen-rich gas from dry and wet bio-renewable materials. Gasification of walnut shell as the main hard nutshell produced in Kurdistan Province of Iran was investigated using a stainless steel batch micro-reactor. Effects of reaction time in the range of $10-30 \mathrm{~min}$, feed loading in the range of $0.06-0.18 \mathrm{~g}$, and temperature in the range of $400-440{ }^{\circ} \mathrm{C}$ were investigated to determine the condition for maximum hydrogen yield. Furthermore, carbon gasification efficiency (CGE) and hydrogen gasification efficiency (HGE) were calculated according to the elemental analysis and the yields of gaseous products. Total gas yield and hydrogen yield were directly correlated with temperature. Steam reforming of walnut shell was favored at higher temperatures. Also, walnut shell loading was inversely correlated with total gas and hydrogen yields while production of methane was favored by higher loading of walnut shell. Furthermore, hydrogen yield increased first, when reaction time increased from 10 to $20 \mathrm{~min}$, and then decreased. Maximum hydrogen yield of $4.63 \mathrm{mmol} / \mathrm{g}$ of walnut shell was obtained at $440{ }^{\circ} \mathrm{C}$, walnut shell loading of $0.06 \mathrm{~g}$ and reaction time of $20 \mathrm{~min}$.
\end{abstract}

Keywords Gasification · Supercritical water · Hydrogen · Walnut shell

Farid Safari

f.safari@srbiau.ac.ir

1 Department of Energy Engineering, Science and Research Branch, Islamic Azad University, Tehran, Iran

2 School of Chemistry, College of Science, University of Tehran, Tehran, Iran

\section{Introduction}

Conventional fossil fuels are being depleted dramatically and the life of many living species has been threatened by the products of their combustion [1]. On the other hand, energy demand is increasing dramatically with population growth and industrialization of developing countries. Using renewable energy resources can be an alternative solution in response to climate change and energy demand related problems [2]. Production, storage and consumption of these renewable resources should be developed such that they positively affect people's preference. Therefore, it seems necessary to research and develop novel renewable energy technologies. Biomass as an organic matter is a rich source of carbon and hydrogen [3]. It is also a versatile resource for producing promising fuels and chemicals such as hydrogen and ethanol [4]. Hydrogen is one of the main products of gasification and regarded by many scientists as key energy carrier of the future with much higher energy density than other conventional fuels [5]. Hydrogen can be used for electricity generation in fuel cells and as an efficient fuel for transportation without any considerable emission [6]. Today most of the hydrogen around the world is produced from fossil fuels especially steam methane reforming. Therefore, biomass-based hydrogen can be a great leap forward in the utilization of renewable energy [7]. Million tons of agricultural wastes are discarded or burned annually around the world. According to the statistic report of Food and Agriculture Organization of the United Nations, Iran is the second largest producer of walnut in the world with a production of 452,000 tons between 2012 and 2013 [8]. These valuable resources have been mainly formed in lignocellulosic structure which consists of lignin, cellulose and hemicellulose [9]. Biomass processing technologies are being developed and some new 
methods have been proposed in recent years. The routes for hydrogen production from biomass have been presented by [10]. Two major routes are defined for biomass-based hydrogen production. Biochemical conversions include biological photosynthesis, biological water-gas shift (WGS) and biological fermentation. Thermochemical conversions include pyrolysis, gasification and supercritical water gasification (SCWG) [11]. Syngas is the main product of biomass gasification which mainly consists of $\mathrm{CO}, \mathrm{CO}_{2}, \mathrm{CH}_{4}$ and $\mathrm{H}_{2}$. Despite the low energy required for biological conversion, it takes too much time for completing the conversion and producing hydrogen. Moreover, experiments should be sustained in an equilibrium condition and any change in conditions disturbs the reactions [12]. SCWG is a hydrothermal treatment of biomass in water media with pressures above 220 bar and temperatures over $374{ }^{\circ} \mathrm{C}$. SCW media prepares a unique condition for conversion of biomass in shorter reaction times with more efficiency $[13,14]$. Water in this condition has much lower dielectric and ionic constant and becomes a unipolar solvent which can easily hydrolyze biomass $[15,16]$. Lignocellulosic structure of biomass is composed of cellulose, hemicellulose and lignin. Cellulose is arranged in bundles while their molecules are interlinked with each other by another molecule named hemicellulose [17]. Lignin holds cellulose and hemicellulose in a network as a binder to form primary cell walls of the plants [18]. Cellulose is made of glucose subunits which have been linked with each other via $\beta$-1,4-glycosidic bonds [19]. Hemicellulose is a branched heteropolysaccharide consisting of $\mathrm{C}_{5}$ sugars (usually xylose and arabinose) and $\mathrm{C}_{6}$ sugars (galactose, glucose, and mannose) as subunits [20]. As mentioned in Eq. (1), hydrolysis of cellulose and hemicellulose takes place in the SCW media to produce fermentable sugars [9].

Cellulose hydrolysis: $\left(\mathrm{C}_{6} \mathrm{H}_{10} \mathrm{O}_{5}\right)_{n}+n \mathrm{H}_{2} \mathrm{O} \rightarrow n \mathrm{C}_{6} \mathrm{H}_{12} \mathrm{O}_{6}$

These fermentable sugars are also dehydrated into 5-HMF (5-hydroxymethylfurfural) [21]. Under a suitable condition, 5-HMFs are degraded into acids, alcohols, aldehydes and ketones [22, 23]. Eventually, these small molecules can be reformed to gaseous products.

Lignin is a natural polymer with no exact structure consisting of phenyl propane with ester bond links. Lignin content is one of the most influential factors limiting the hydrolysis [24]. Lignin's hydrolysis in SCW, followed by dealkylation, promotes the decomposition of lignin. As mentioned in Eq. (2), phenolic compounds such as syringols, guaiacols are formed to convert into polyphenols further [25].

Lignin hydrolysis: $\left(\mathrm{C}_{10} \mathrm{H}_{10} \mathrm{O}_{3}\right)_{n}+n \mathrm{H}_{2} \mathrm{O} \rightarrow n \mathrm{C}_{10} \mathrm{H}_{12} \mathrm{O}_{4}$
Overall, the interaction between lignin, cellulose and hemicellulose in SCWG is not clearly specified. However, the amount of cellulose and hemicellulose and their availability in the structure can affect the conversion of lignocellulosic biomass into gaseous products.

It seems necessary to have a look at the main reactions occur during SCWG process to understand the effect of different parameters on gasification's procedure. It is reported by many researchers that biomass gasification in SCW media is a complex process, but the overall chemical conversion can be represented by the simplified net reaction (3) [15]:

$$
\begin{aligned}
& \mathrm{CH}_{x} \mathrm{O}_{y}+(2-y) \mathrm{H}_{2} \mathrm{O} \rightarrow \mathrm{CO}_{2}+\left(2-y+\frac{x}{2}\right) \mathrm{H}_{2}, \\
& \Delta \mathrm{H} \gg 0
\end{aligned}
$$

where $x$ and $y$ are the elemental molar ratios of $\mathrm{H} / \mathrm{C}$ and $\mathrm{O} /$ $\mathrm{C}$ in biomass, respectively. In addition, a group of competing reactions take place to complete the successful gasification which are mentioned in Eqs. (4), (5) and (6) [15].

Steam reforming:

$$
\begin{aligned}
\mathrm{CH}_{x} \mathrm{O}_{y} & +(1-y) \mathrm{H}_{2} \mathrm{O} \rightarrow \mathrm{CO}+\left(1-y+\frac{x}{2}\right) \mathrm{H}_{2} \\
\Delta \mathrm{H} & =310\left(\frac{\mathrm{KJ}}{\mathrm{mol}}\right)
\end{aligned}
$$

Water-gas shift:

$\mathrm{CO}+\mathrm{H}_{2} \mathrm{O} \rightarrow \mathrm{CO}_{2}+\mathrm{H}_{2} \quad \Delta \mathrm{H}=-41\left(\frac{\mathrm{KJ}}{\mathrm{mol}}\right)$

Methanation:

$\mathrm{CO}+3 \mathrm{H}_{2} \rightarrow \mathrm{CH}_{4}+\mathrm{H}_{2} \mathrm{O} \quad \Delta \mathrm{H}=-206\left(\frac{\mathrm{KJ}}{\mathrm{mol}}\right)$

In the methanation reaction, 3 mol of produced hydrogen are consumed by Eq. (6) for producing $1 \mathrm{~mol}$ of methane. Also, water-gas shift reaction consumes $\mathrm{CO}$ and water and produces $\mathrm{H}_{2}$ and $\mathrm{CO}_{2}$. Therefore, for hydrogenselective SCWG process, methanation reaction should be decelerated.

Many experiments have been conducted for SCWG of biomass model compounds [25-27]. However, some research has been done for gasification of agricultural wastes and real biomasses. Useful reviews for SCWG of biomass have been proposed by Kruse, Guo et al. and Tekin et al. [28-30]. Rashidi et al. performed SCWG of bagasse using the same reactor with and without Ni/CNTs catalysts. The effect of bagasse loading and reaction times on hydrogen yield was studied. Hydrogen yield of $3.84 \mathrm{mmol} / \mathrm{g}$ was observed for non-catalytic tests at the temperature of $400{ }^{\circ} \mathrm{C}$, the reaction time of $20 \mathrm{~min}$, and bagasse loading of $0.15 \mathrm{~g}$ [31]. Safari et al. reported the 
gasification performances of three different agricultural wastes including walnut shell and almond shell in a base case condition [32]. Madenoglu et al. investigated the subcritical and SCWG of some hard nutshells in the absence and presence of the catalyst. Effect of temperature and catalyst was investigated on gaseous, liquid and solid products. Hydrogen yield was enhanced by increasing the temperature from 400 to $600{ }^{\circ} \mathrm{C}$ [33]. Liu et al. reported the product identification and distribution from hydrothermal conversion of walnut shells into liquefied products using $\mathrm{KOH}$ and $\mathrm{Na}_{2} \mathrm{CO}_{3}$ catalysts [34]. However, none of the previous studies performed a holistic analysis of gaseous products of SCWG of walnut shell.

The objective of this study is to investigate the hydrothermal gasification of Iranian walnut shell in SCW media for hydrogen-rich gas production. All of the main important parameters including temperature, feed content and reaction time were studied to observe the variation of gaseous products and to determine the optimum condition for hydrogen yield. Also, the simultaneous effect of reaction time and feed concentration was studied. Gasification efficiencies are also calculated using elemental analysis of walnut shell and the yield of the gaseous products. There is no work in the literature with a holistic analysis of hydrothermal gasification of walnut shell and its gaseous products. Therefore, the present study aims to study the gaseous products of walnut shell holistically and determine the optimum condition for hydrogen production.

\section{Materials and methods}

\section{Materials}

Walnut shell was provided by agriculture gardens around Sanandaj, located in Kurdistan Province of Iran. It was first washed and then dried in atmospheric condition for $48 \mathrm{~h}$. After that, they were ground and sieved in three steps to obtain the desired particle size (diameter $<150 \mu \mathrm{m})$. The elemental analysis of the prepared walnut shell was conducted by a CHNS analyzer (Vario EL III by Elementar, Germany) for characterization. As presented in Table 1,

Table 1 Elemental analysis of Iranian walnut shell the $\mathrm{C}$ and $\mathrm{H}$ contents are $55.87 \%$. The mass fraction of oxygen in biomass is determined by Eq. (7):

$$
\mathrm{O} \%=100-\mathrm{C} \%-\mathrm{H} \%-\mathrm{N} \%-\mathrm{S} \%-\mathrm{Ash} \%
$$

\section{Reaction setup and experimental outline}

Schematic of the reactor system and experimental setup is indicated in Fig. 1. Stainless steel batch micro-reactor with total volume of $25 \mathrm{~mL}$ has been used in this work. 0.06 , 0.12 and $0.18 \mathrm{~g}$ of feedstock were added to $6 \mathrm{~g}$ of deionized water to make three mixtures with different concentrations. Argon as an inert gas stream was used for vacating the reactor and removing air for several minutes. The mixtures were injected into the reactor by a syringe. The reactor was immersed in a molten salt bath containing a mixture of potassium nitrate, sodium nitrate, and sodium nitrite. The molten salt bath temperature was measured using a K-type thermocouple and was controlled by a PID temperature controller in determined temperature. Figure 2 indicates the temporal variation of pressure inside the reactor in the mentioned conditions. The SCW condition was gained after approximately 2 min after the immersion of reactor inside the molten salt bath. For each experiment, after a certain reaction time, the reactor was taken out of the molten salt bath and immersed in a water bath for cooling down to room temperature. The final pressure of reaction was measured using a low-pressure gage after opening the high-pressure valve. The volume of the gaseous product was measured using a gasometer. The gas

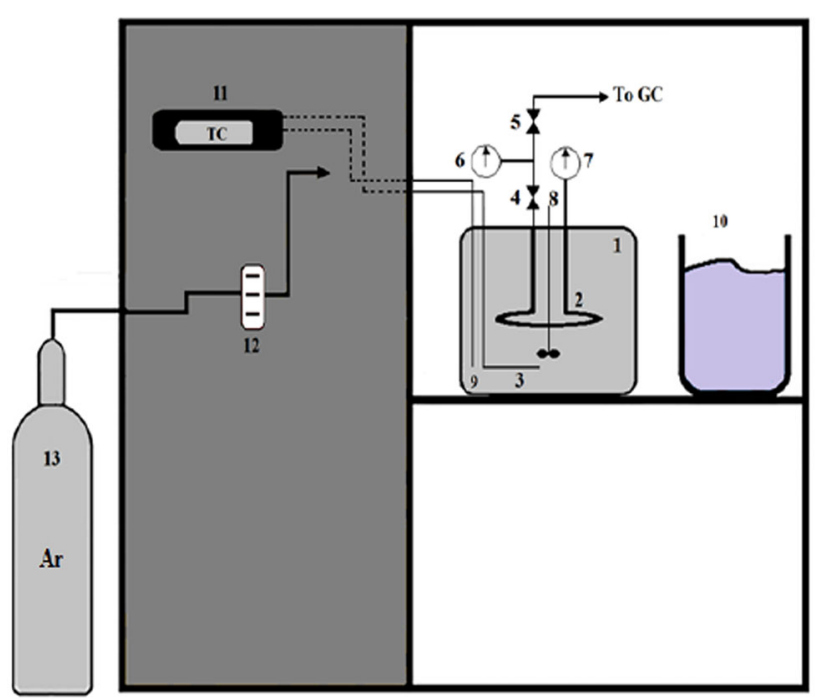

Fig. 1 Schematic of reactor system: 1 molten salt bath, 2 tubular batch reactor, 3 electrical heater, 4 high-pressure valves, 5 lowpressure valve, 6 low-pressure gage, 7 high-pressure gage, 8 mixer, 9 k-type thermocouple, 10 water bath, 11 temperature controller, 12 flow meter and 13 argon gas bottle 


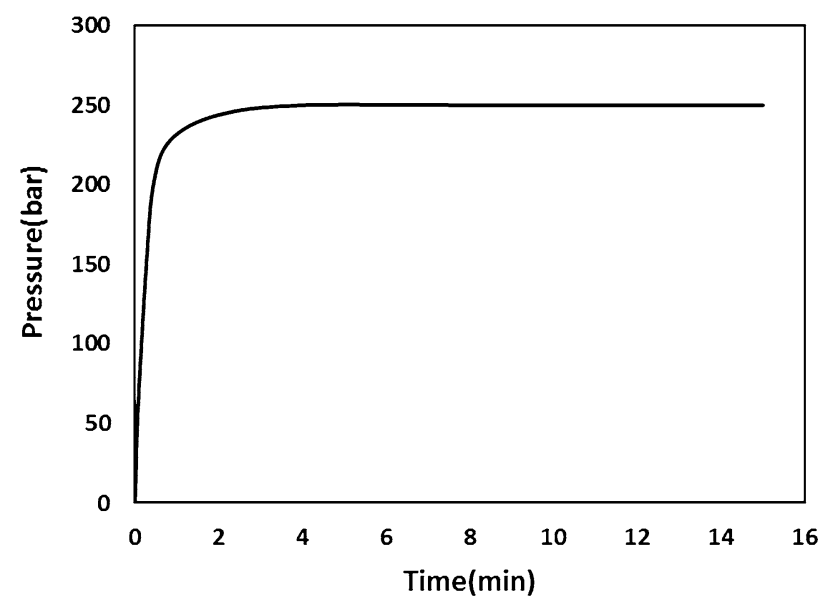

Fig. 2 Temporal variation of reactor's pressure $\left(T: 440{ }^{\circ} \mathrm{C}, 0.06 \mathrm{~g}\right.$ walnut shell, $6 \mathrm{~g}$ water)

volume was measured with $\pm 5 \%$ accuracy. Experiments were performed three times under the same experimental conditions and reported data are the averages of three replicates.

\section{Product analysis method}

Gas samples were taken using tight syringes and injected into the gas chromatograph's column. Gas chromatograph (Varian 3400 and Teyfgostar-Compact) was equipped with PORAPAK Q-S 80/100 (30 m long, 0.53 mm I.D) column, a methanizer and flame ionization detector (FID). Argon was used as carrier gas and oven temperature program was in the following: $40{ }^{\circ} \mathrm{C}$ isothermal for $5 \mathrm{~min}$, increase in temperature from 40 to $75^{\circ} \mathrm{C}$ in $17.5 \mathrm{~min}$ and isothermal in $75^{\circ} \mathrm{C}$ for $5 \mathrm{~min}$. The methanizer option enables the FID to detect levels of $\mathrm{CO}$ and $\mathrm{CO}_{2}$. During analysis, methanizer is heated to $380{ }^{\circ} \mathrm{C}$ with the FID detector body. When the column effluent mixes with the FID hydrogen supply and passes through the methanizer, $\mathrm{CO}$ and $\mathrm{CO}_{2}$ are converted to methane. GC was calibrated with standard gas mixture supplied by ROHAM Company in Tehran, Iran. The standard deviation for the results of gas composition was calculated to be $\pm 2 \%$.

Reported data are the averages of several observations for each experiment for more reproducibility of data. Also, the accuracy of data collection and comparison between means of compositions and yields from the processing of two samples was studied through ANOVA (analysis of variance). The statistical level was $5 \%$ with $p<0.05$. Gaseous products have been presented in the form of gas yield which is the mmoles of the gaseous products in $1 \mathrm{~g}$ of walnut shell. Elemental analysis is used to determine the CGE which is the ratio of the amount of carbon in the produced gasses to the amount of carbon in the initial walnut shell and HGE which is the ratio of the amount of hydrogen in the gaseous products to the amount of hydrogen in the initial walnut shell. Mathematically, CGE and HGE are defined by Eqs. 8 and 9 [25]:

$\mathrm{CGE}=\frac{(\text { Moles of carbon in gaseous products })}{(\text { Moles of carbon in walnut shell })}$
$\mathrm{HGE}=\frac{(\text { Moles of hydrogen in gaseous products })}{\text { (Moles of hydrogen in walnut shell })}$

\section{Results and discussion}

Results for SCWG of walnut shell will be presented in this section. The effect of operating conditions including temperature, reaction time and biomass loading on the gaseous product yields, CGE and HGE will be presented first, and then the combination of these effects will be analyzed. The total gaseous product presented in the results is the sum of main gaseous components including $\mathrm{CO}, \mathrm{CO}_{2}, \mathrm{H}_{2}$ and $\mathrm{CH}_{4}$. Table 2 presents the summary of the different conditions and the results of gasification. Temperature varied between 400 and $440{ }^{\circ} \mathrm{C}$ while biomass loading changed in the range of $0.06-0.18 \mathrm{~g}$. Moreover, reaction times of 10 , 20 and 30 min were considered for study the effect of the residence time of the biomass in the reactor.

\section{Effect of temperature}

As shown in Fig. 3, an increase in temperature from $400{ }^{\circ} \mathrm{C}$ to reactor's maximum temperature $\left(440{ }^{\circ} \mathrm{C}\right)$, enhances endothermic reforming reaction of walnut shell in SCW and increases the total gas yield. Variations of individual gas yields against temperature are shown in Fig. 4. As seen, increasing temperature leads to increasing of $\mathrm{H}_{2}$, $\mathrm{CO}_{2}$, and $\mathrm{CO}$ yields while $\mathrm{CH}_{4}$ decreases slightly. It can be concluded that increase in temperature has a significant effect on SCWG process and enhances total gas yield through promoting of reforming reaction. In addition, due to endothermic nature of overall reaction mentioned in Eq. (3), experiments should be performed at the allowable high temperatures. Thus, the best temperature for the conversion of walnut shell into gas products for our lab instruments is $440{ }^{\circ} \mathrm{C}$.

\section{Effect of reaction time}

Reaction time increased from 10 to 30 min for investigating the effect of resident time of biomass in the reactor on gaseous products and gasification efficiencies. Experiments performed at least three times for each reaction time and the averages are reported in Figs. 5 and 6. 
Table 2 Summary of experimental conditions and SCWG results

\begin{tabular}{|c|c|c|c|c|c|c|c|c|}
\hline \multirow[t]{2}{*}{ Test\# } & \multirow[t]{2}{*}{ Temperature $\left({ }^{\circ} \mathrm{C}\right)$} & \multirow[t]{2}{*}{ Reaction time (min) } & \multirow[t]{2}{*}{ Feed/water (mass ratio) } & \multicolumn{5}{|c|}{ Main gas yields (mmole gas/g of walnut shell) } \\
\hline & & & & $\mathrm{CO}$ & $\mathrm{CH}_{4}$ & $\mathrm{CO}_{2}$ & $\mathrm{H}_{2}$ & Total \\
\hline 1 & 400 & 20 & 0.01 & 1.63 & 2.46 & 7.98 & 2.44 & 14.51 \\
\hline 2 & 410 & 20 & 0.01 & 2.02 & 2.21 & 9.41 & 3.17 & 16.81 \\
\hline 3 & 420 & 20 & 0.01 & 2.53 & 2.14 & 11.59 & 3.34 & 19.6 \\
\hline 4 & 430 & 20 & 0.01 & 2.71 & 1.83 & 12.81 & 4.12 & 21.47 \\
\hline 5 & 440 & 20 & 0.01 & 2.62 & 1.62 & 13.48 & 4.63 & 22.35 \\
\hline 6 & 440 & 10 & 0.01 & 3.12 & 0.76 & 12.28 & 3.86 & 20.02 \\
\hline 7 & 440 & 30 & 0.01 & 2.31 & 2.77 & 14.22 & 3.92 & 23.22 \\
\hline 8 & 440 & 10 & 0.02 & 2.77 & 1.48 & 8.63 & 2.68 & 15.56 \\
\hline 9 & 440 & 20 & 0.02 & 1.45 & 3.13 & 9.47 & 2.89 & 16.94 \\
\hline 10 & 440 & 30 & 0.02 & 1.82 & 2.28 & 11.8 & 3.47 & 19.37 \\
\hline 11 & 440 & 10 & 0.03 & 1.99 & 2.85 & 5.92 & 1.94 & 12.7 \\
\hline 12 & 440 & 20 & 0.03 & 1.38 & 3.32 & 6.32 & 2.14 & 13.16 \\
\hline 13 & 440 & 30 & 0.03 & 1.18 & 3.99 & 8.64 & 1.66 & 15.47 \\
\hline
\end{tabular}

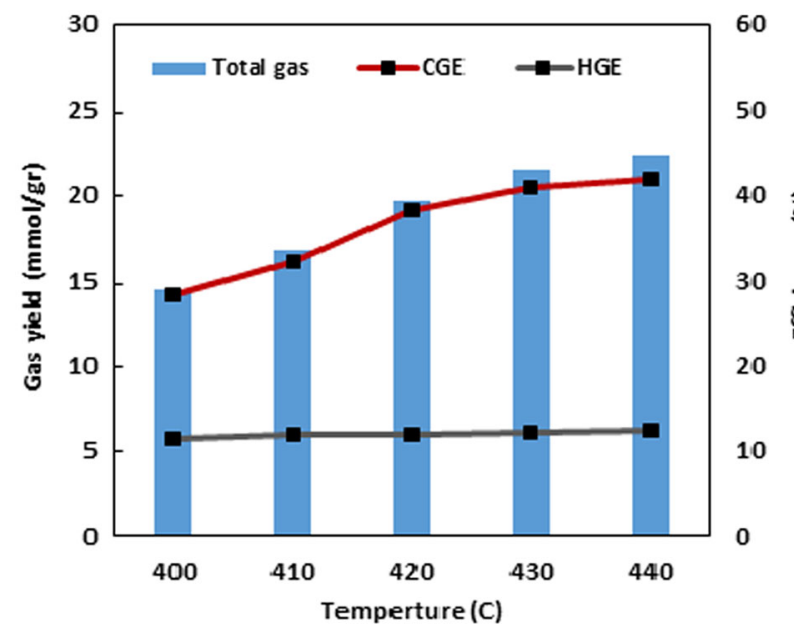

Fig. 3 Effect of temperature on total gas yield and efficiencies of walnut shell gasification (reaction time $20 \mathrm{~min}$, walnut shell loading $0.06 \mathrm{~g}$, water loading $6 \mathrm{~g}$ )

Figure 5 depicts that hydrogen yield increases by increasing the reaction time, reaches a maximum at the reaction time of $20 \mathrm{~min}$ and then starts to decrease. The aim of this study is to optimize hydrogen production in SCWG of walnut shell. Hence, $20 \mathrm{~min}$ is the optimum reaction time for maximum yield of hydrogen when reaction time deviates from 10 to $30 \mathrm{~min}$.

Methane yield also increased by a factor of 3.64. Extending the reaction time increases the methane yield from 0.39 to 1.22 ( $\mathrm{mmol}$ gas $/ \mathrm{g}$ of walnut shell). As reaction time increased from 10 to $20 \mathrm{~min}$, the methane yield increased, while the total gasification yield increased by a factor of 1.28. Beyond $20 \mathrm{~min}$ of reaction time, the total

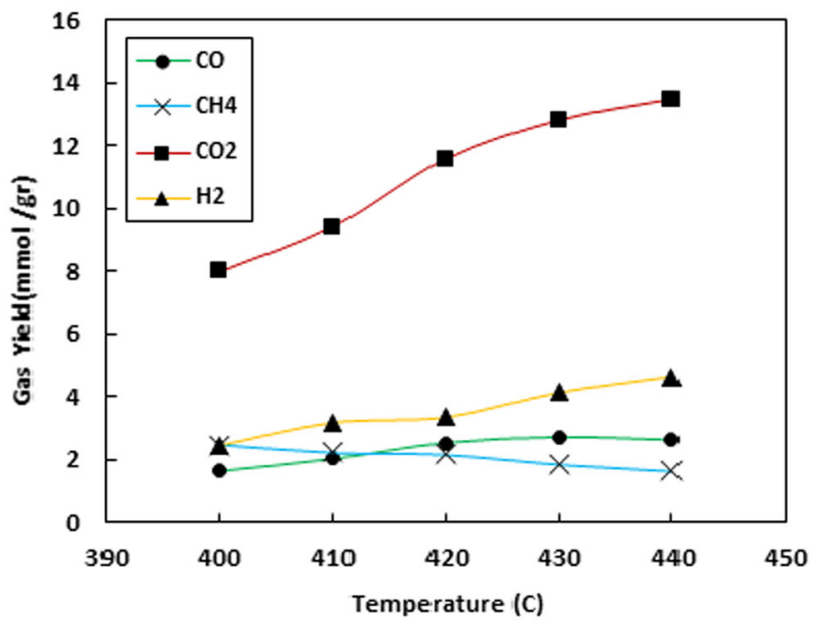

Fig. 4 Effect of temperature on the yield of main gaseous products of walnut shell gasification (reaction time $20 \mathrm{~min}$, walnut shell loading $0.06 \mathrm{~g}$, water loading $6 \mathrm{~g}$ )

yield of the product gas was not changed significantly while the composition continued to change. The decrease in hydrogen yield and increase in the methane yield can be associated to the methanation process (Eq. 7). According to Eq. (7), consuming $3 \mathrm{~mol} \mathrm{H}_{2}$ generates $1 \mathrm{~mol} \mathrm{CH}_{4}$ and consumes $1 \mathrm{~mol} \mathrm{CO}$. Meanwhile, downward trend of $\mathrm{H}_{2}$ yield should be sharper than the rising trend of $\mathrm{CH}_{4}$ and $\mathrm{CO}$ yields. When the objective of biomass gasification in SCW is hydrogen production, reaction (7) must be restrained and $\mathrm{CO}$ reacting with water to form $\mathrm{CO}_{2}$ and $\mathrm{H}_{2}$ (Eq. 6) must be enhanced. Figure 5 also shows that the yield of $\mathrm{CO}_{2}$ increases as reaction time increases from 10 to $30 \mathrm{~min}$. This figure also shows that the $\mathrm{CO}$ yield 


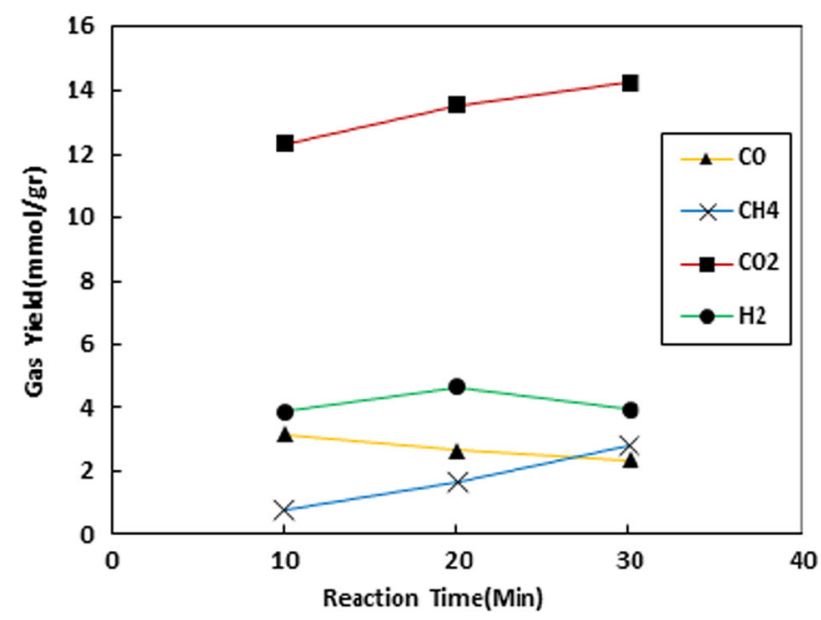

Fig. 5 Temporal variation of main gaseous products of walnut shell (T: $440{ }^{\circ} \mathrm{C}$, walnut shell loading $0.06 \mathrm{~g}$, water loading $6 \mathrm{~g}$ )

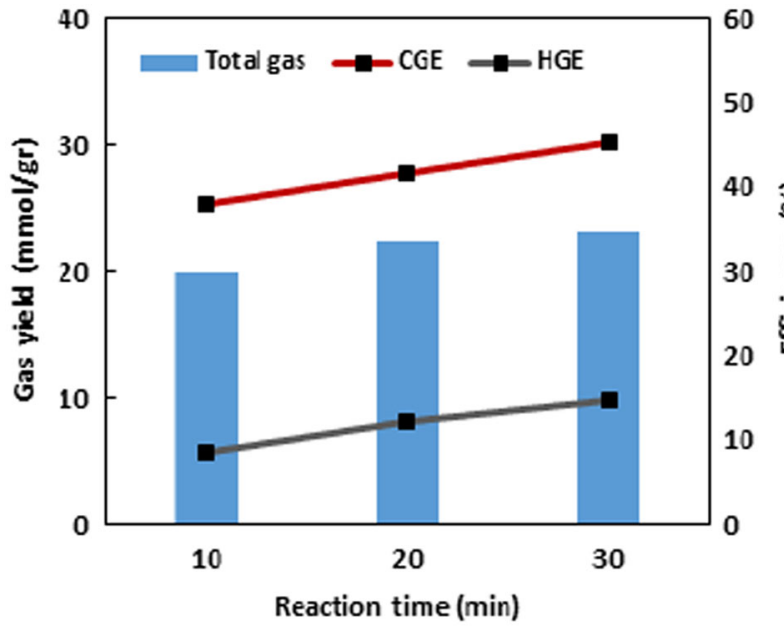

Fig. 6 Effect of reaction time on total gas yield and efficiencies of walnut shell gasification $\left(T: 440{ }^{\circ} \mathrm{C}\right.$, walnut shell loading $0.06 \mathrm{~g}$, water loading $6 \mathrm{~g}$ )

decreases with time slightly which is due to the reaction of $\mathrm{CO}$ with water to form $\mathrm{CO}_{2}$ and $\mathrm{H}_{2}$ by increasing time. As shown in Fig. 6, the amount of total generated gas increased from 20.02 to 23.22 ( $\mathrm{mmol} / \mathrm{g}$ of walnut shell) when reaction time increased from 10 to $30 \mathrm{~min}$.

\section{Effect of walnut shell loading}

Figure 7 shows the total gas yield as a function of walnut shell loading. The walnut shell loading changed from 0.06 to $0.18 \mathrm{~g}$ while the amount of water loading was fixed at $6 \mathrm{~g}$. As walnut shell loading increased, $\mathrm{H}_{2}$ and $\mathrm{CO}_{2}$ yields decreased by factors of 2.17 and 2.13 , respectively. In addition, $\mathrm{CO}$ yield decreased from 1.622 to $1.084(\mathrm{mmol} / \mathrm{g}$ of walnut shell). The increment in the ratio of walnut shell to water decelerates the steam reforming reaction on

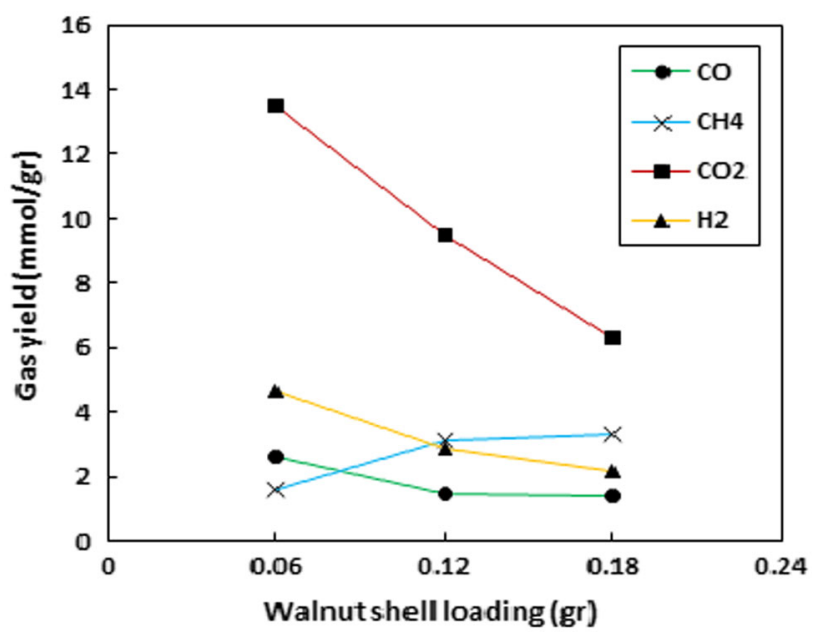

Fig. 7 Effect of biomass loading on total gas yield, CGE, and HGE of walnut shell gasification $\left(T: 440{ }^{\circ} \mathrm{C}\right.$, reaction time $20 \mathrm{~min}$, water loading $6 \mathrm{~g}$ )

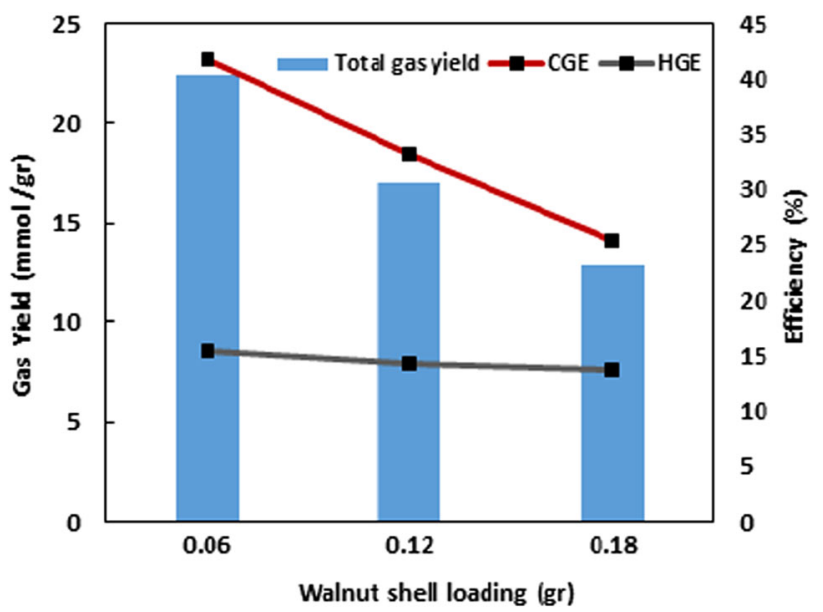

Fig. 8 Effect of feed loading on total gas yield, CGE and HGE of SCWG of walnut shell $\left(T: 440{ }^{\circ} \mathrm{C}\right.$, reaction time $20 \mathrm{~min}$, water loading $6 \mathrm{~g}$ )

Eq. (5), which is followed by a decrease in walnut shell conversion and total gas yield. However, there is an increase in the methane yield which is due to the consumption of $\mathrm{CO}$ and $\mathrm{H}_{2}$ to produce methane (Eq. 7) at lower water/walnut shell ratios.

As shown in Fig. 8, the total gas yield decreased dramatically by increasing the concentration of walnut shell. Increasing walnut shell concentration from 0.06 to $0.18 \mathrm{~g}$ decreased the total gas yield from 22.36 to 12.86 (mmol gas/g of walnut shell). Moreover, CGE and HGE decreased when walnut shell loading increased. CGE decreased sharply from 41.7 to $25.2 \%$, while HGE decreased slightly from 15.38 to $13.67 \%$.

Figure 9 indicates the simultaneous effect of reaction time and feed loading on hydrogen yield. The highest hydrogen yield was observed at the lowest walnut shell 


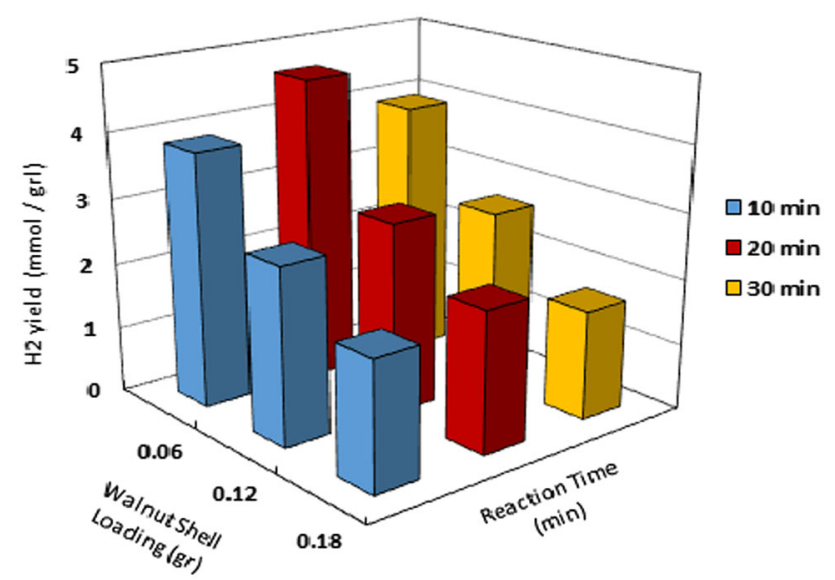

Fig. 9 Comparison of hydrogen yields at various reaction times and walnut shell loadings $\left(T 440{ }^{\circ} \mathrm{C}\right.$, water loading $\left.6 \mathrm{~g}\right)$

loading of $0.06 \mathrm{~g}$ and at the optimum reaction time of $20 \mathrm{~min}$. It can also be perceived that the effect of feed loading is much more significant than the effect of reaction time on hydrogen yield.

Compared to the previous study of SCWG of walnut shell, this study resulted in the $\mathrm{H}_{2}$ yield of $2.44 \mathrm{mmol} / \mathrm{g}$ in $400{ }^{\circ} \mathrm{C}$, which was slightly higher than that of Madenoglu et al. Also, the methane yield was nearly the same. There is no previous study on SCWG of Iranian walnut. Hence, this research presents a sustainable way for utilization of this bio-renewable agricultural waste.

\section{Conclusion}

The results of this study promise a sustainable process for making an alternative fuel from walnut shell which is an agricultural waste. Gasification of walnut shell in SCW media was performed under 13 different conditions to observe the effect of parameters including temperature, feed content and reaction time on the yields of main gaseous products considering the main reactions of the process. Promising results were obtained using holistic and comprehensive analysis of gaseous products and affecting parameters, for waste management sector and energy industry of Iran which has not been studied before. Ranges of variation of parameters were determined, considering the capacity of the reactor system and the obtained results from the literature. The temperature had a significant effect on the total gas and hydrogen yield so that as temperature increased, hydrogen yield increased while increasing the temperature may cause intensive energy consumption. So, the appropriate range of temperature was considered between 400 and $440{ }^{\circ} \mathrm{C}$ and the maximum hydrogen yield occurred in $440{ }^{\circ} \mathrm{C}$. The effects of reaction time and walnut shell loading were investigated at this temperature. The maximum hydrogen yield of 4.63 (mmol gas/g of walnut shell) was observed at the reaction time of $20 \mathrm{~min}$, walnut shell loading of $0.06 \mathrm{~g}$ and temperature of $440{ }^{\circ} \mathrm{C}$.

Acknowledgments The authors would like to thank the Iran Renewable Energy Organization (SUNA) for their kind support of this research.

Open Access This article is distributed under the terms of the Creative Commons Attribution 4.0 International License (http://crea tivecommons.org/licenses/by/4.0/), which permits unrestricted use, distribution, and reproduction in any medium, provided you give appropriate credit to the original author(s) and the source, provide a link to the Creative Commons license, and indicate if changes were made.

\section{References}

1. Ahmadi P, Dincer I, Rosen MA (2012) Exergo-environmental analysis of an integrated organic Rankine cycle for trigeneration. Energy Convers Manag 64:447-453

2. Chiari L, Zecca A (2011) Constraints of fossil fuels depletion on global warming projections. Energy Policy 39:5026-5034

3. Ballarin A, Vecchiato D, Tempesta T, Marangon F, Troiano S (2011) Biomass energy production in agriculture: a weighted goal programming analysis. Energy Policy 39:1123-1131

4. Tavasoli A, Barati M, Karimi A (2015) Conversion of sugarcane bagasse to gaseous and liquid fuels in near-critical water media using $\mathrm{K}_{2} \mathrm{O}$ promoted $\mathrm{Cu} / \gamma-\mathrm{Al}_{2} \mathrm{O}_{3}-\mathrm{MgO}$ nanocatalysts. Biomass Bioenerg 80:63-72

5. Dincer I, Zamfirescu C (2012) Sustainable hydrogen production options and the role of IAHE. Int J Hydrog Energy 37:16266-16286

6. Dincer I (2012) Green methods for hydrogen production. Int J Hydrog Energy 37:1954-1971

7. Midilli A, Dincer I (2008) Hydrogen as a renewable and sustainable solution in reducing global fossil fuel consumption. Int $\mathrm{J}$ Hydrog Energy 33:4209-4222

8. Faostat annual report 2013. http://faostat3.fao.org/. Accessed Oct 2015

9. Pavlovi I, Knez Z, Skerget M (2013) Hydrothermal reactions of agricultural and food processing wastes in sub- and supercritical water: a review of fundamentals, mechanisms, and state of research. J Agric Food Chem 61:8003-8025

10. Hepbasli A, Kalinci Y, Dincer I (2009) Biomass-based hydrogen production: a review and analysis. Int $\mathrm{J}$ Hydrog Energy 34:8799-8817

11. Saxena RC, Seal D, Kumar S, Goyal HB (2008) Thermo-chemical routes for hydrogen rich gas from biomass: a review. Renew Sust Energ Rev 12:1909-1927

12. Das D, Veziroglu TN (2001) Hydrogen production by biological processes: a survey of literature. Int J Hydrog Energy 26:13-28

13. Basu P, Mettanant V (2009) Biomass gasification in supercritical water-a review. Int J Chem React Eng 7:1542-6580

14. JaranaMB Garcia, Sanchez-Oneto J, Portela JR, Nebot Sanz E, de la OssaEJ Martinez (2008) Supercritical water gasification of industrial organic wastes. J Supercrit Fluid 46:329-334

15. Barati M, Tavasoli A, Babatabar M, Dalai AK, Das U (2014) Hydrogen production via supercritical water gasification of bagasse using unpromoted and zinc promoted $\mathrm{Ru} / \gamma-\mathrm{Al} 2 \mathrm{O} 3$ nanocatalysts. Fuel Proc Tech 123:140-148

16. Calzavara Y, Dubien CJ, Boissonnet G, Sarrade S (2005) Evaluation of biomass gasification in supercritical water process for hydrogen production. Energ Convers Manag 46:615-631 
17. Huber GW, Dumesic JA (2006) An overview of aqueous-phase catalytic processes for production of hydrogen and alkanes in a biorefinery. Catal Today 111:119-132

18. Waldner MH, Vogel F (2005) Renewable production of methane from woody biomass by catalytic hydrothermal gasification. Ind Eng Chem Res 44:4543-4551

19. Kobayashi H, Fukuoka A (2013) Synthesis and utilisation of sugar compounds derived from lignocellulosic biomass. Green Chem 15:1740-1763

20. Murphy JD, McCarthy K (2005) Ethanol production from energy crops and wastes for use as a transport fuel in Ireland. Appl Energy 82:148-166

21. Mohan D, Pittman CU, Steele PH (2006) Pyrolysis of wood/ biomass for bio-oil: a critical review. Energy Fuel 20:848-889

22. Minowa T, Fang Z (1998) Hydrogen production from cellulose in hot compressed water using reduced nickel catalyst: product distribution at different reaction temperatures. J Chem Eng Jpn 31:488-491

23. Reddy SN, Nanda S, Dalai AK, Kozinski JA (2014) Supercritical water gasification of biomass for hydrogen production. Int $\mathbf{J}$ Hydrog Energy 39:6912-6926

24. Salimi M, Safari F, Tavasoli A, Shakeri A (2016) Hydrothermal gasification of different agricultural wastes in supercritical water media for hydrogen production: a comparative study. Int $\mathbf{J}$ Ind Chem 7:277-285

25. Resende FLP, Fraley SA, Berger MJ, Savage PE (2008) Noncatalytic gasification of lignin in supercritical water. Energy Fuel 22:1328-1334

26. Azadi P, Khan S, Stroble F, Azadi F, Farnood R (2012) Hydrogen production from cellulose, lignin, bark and model carbohydrates in supercritical water using nickel and ruthenium catalysts. Appl Catal B Environ 117-118:330-338

27. Susanti RF, Dianningrum LW, Yum T, Kim Y, Gwon B, Kim J (2012) High-yield hydrogen production from glucose by supercritical water gasification without added catalyst. Int J Hydrog Energy 37:11677-11690

28. Kruse A (2009) Hydrothermal biomass gasification. J Supercritic Fluid 47:391-399

29. Guo Y, Wang SZ, Xu DH, Gong YM, Ma HH, Tang XY (2010) Review of catalytic supercritical water gasification for hydrogen production from biomass. Renew Sust Energ Rev 14:334-343

30. Tekin et al (2014) A review of hydrothermal biomass processing. Renew Sust Energ Rev 40:673-687

31. Rashidi M, Tavasoli A (2015) Hydrogen rich gas production via supercritical water gasification of sugarcane bagasse using unpromoted and copper promoted Ni/CNT nanocatalysts. J Supercrit Fluid 98:111-118

32. Safari F, Tavasoli A, Ataei A, Choi JK (2015) Hydrogen and syngas production from gasification of lignocellulosic biomass in supercritical water media. Int $\mathbf{J}$ Recycl Org Waste Agric 4:121-125

33. Madenoglu TG, Yildirir E, Saglam M, Yuksel M, Ballice L (2014) Improvement in hydrogen production from hard-shell nut residues by catalytic hydrothermal gasification. J Supercrit Fluid 67:22-28

34. Liu WJ, Jiang H, Yu HQ (2015) Thermochemical conversion of lignin for functional materials: A review and future direction. Green Chem. doi:10.1039/C5GC01054C (accepted manuscript) 